\title{
A CRIAÇÃO MUSICAL NA PERSPECTIVA DAS PEDAGOGIAS MUSICAIS ABERTAS
}

MUSICAL CREATION FROM THE PERSPECTIVE OF OPEN MUSICAL PEDAGOGIES

CREACIÓN MUSICAL DESDE LA PERSPECTIVA DE LAS PEDAGOGÍAS MUSICALES ABIERTAS

Glauber Resende Domingues ${ }^{1}$ Universidade Federal do Rio de Janeiro (UFRJ) glauber.rd@gmail.com 


\section{Resumo}

Este artigo apresenta a criação musical nas pedagogias musicais abertas, trazendo um panorama sobre a temática. Traremos, na primeira parte, uma caracterização histórica e conceitual sobre como tais pedagogias foram sendo forjadas. Cabe, neste sentido, sinalizar o marco da criação do Foro Latinoamericano de Educación Musical (FLADEM), que foi se tornando o espaço de debate sobre tais pedagogias. A seguir dissertaremos sobre a perspectiva de criatividade/criação musical e como esta foi sendo construída, principalmente a partir das ideias de Violeta Hemsy de Gainza. $\mathrm{Na}$ terceira parte discorreremos sobre o tripé formação, atuação e avaliação em práticas criativas na educação musical. Por fim, apresentaremos algumas propostas criativas de autores orientados pelas pedagogias abertas a partir de três eixos: experiências musicais centradas na prática, práxis musical participativa e práxis musical integrada. Nas considerações finais comentaremos sobre o alargamento conceitual das pedagogias abertas e a emergência de novas questões para a educação musical.

Palavras Chave: Educação Musical Latino-americana. FLADEM. Pedagogias Musicais Abertas. Criação musical.

\section{Abstract}

This article presents musical creation in open musical pedagogies, providing an overview of the theme. We will bring, in the first part, a historical and conceptual characterization of how such pedagogies were being forged. In this sense, it is worth pointing out the landmark of the creation of the Foro Latinoamericano de Educación Musical (FLADEM), which became the space for debate on such pedagogies. Next, we will speak about the perspective of creativity/musical creation and how it was built, mainly from the ideas of Violeta Hemsy de Gainza. In the third part we will speak about the formation, acting and evaluation in creative practices in music education. Finally, we will present some creative proposals from authors guided by open pedagogies based on three axes: musical experiences centered on practice, participatory musical praxis and integrated musical praxis. In the final considerations, we will comment about the conceptual expansion of open pedagogies and the emergence of new issues for music education.

Keywords: Latin American Music Education. FLADEM Open Musical Pedagogies. Musical creation.

\footnotetext{
1. Doutor e mestre em Educação e licenciado em Música pela UFRJ. Docente do Colégio de Aplicação da UFRJ, atuando na Educação Básica e na Formação de Professores de Música. Coordena o Projeto de Articulação Institucional "Arte na educação básica: criação, formação e resistência" e o projeto de pesquisa "Gêneros musicais latino-americanos na Educação Básica: abordagens interseccionais". Docente permanente no Mestrado Profissional em Ensino das Práticas Musicais da UNIRIO. Atual presidente do Fladem Brasil (Seção brasileira do Foro Latino-Americano de Educación Musical). Pesquisa epistemologias latino-americanas (do ensino) da Música e as questões de gênero e sexualidade na Educação Musical.
} 


\section{Resumen}

Este artículo presenta la creación musical en las pedagogías musicales abiertas, proporcionando una visión general del tema. Traeremos, en la primera parte, una caracterización histórica y conceptual de cómo se fueron forjando tales pedagogías. En este sentido, cabe señalar la creación del Foro Latinoamericano de Educación Musical (FLADEM), que se convirtió en el espacio de debate sobre estas pedagogías. A continuación, hablaremos sobre la perspectiva de la creatividad/creación musical y cómo se construyó, principalmente a partir de las ideas de Violeta Hemsy de Gainza. En la tercera parte hablaremos sobre la formación, ejecución y evaluación de trípodes en prácticas creativas en educación musical. Finalmente, presentaremos algunas propuestas creativas de autores guiados por pedagogías abiertas basadas en tres ejes: experiencias musicales centradas en la práctica, praxis musical participativa y praxis musical integrada. En las consideraciones finales, comentaremos la expansión conceptual de las pedagogías abiertas y el surgimiento de nuevos temas para la educación musical.

Palavras Chave: Educación Musical Latinoamericana. FLADEM. Pedagogías musicales abiertas. Creación musical. 


\section{Introdução}

Este artigo, de caráter eminentemente histórico e descritivo, pretende apresentar questões a respeito das abordagens da criação musical sob a perspectiva das pedagogias musicais abertas. Para tanto, percorrerá alguns aspectos históricos do pensamento pedagógico-musical latino-americano recente, para que assim se possa compreender o conceito de pedagogias musicais abertas e os seus lócus de construção.

Antes de qualquer coisa, pensamos ser importante esboçar uma ideia de América Latina, explicitando que este nosso continente sofreu um forte processo colonizador que deixou vestígios importantes. Com isso, é preciso reiterar que, por mais que tenhamos interesse em nossos processos pedagógico-musicais e trazer à tona o nosso processo identitário, não é uma tarefa fácil por causa das marcas da colonialidade em nossas sociedades latino-americanas.

Por causa do processo de colonização, os países de nosso continente sofrem ainda hoje com desigualdades sociais, econômicas e culturais. No primeiro caso, é preciso dizer que as pessoas não usufruem do mesmo acesso aos mesmos aparatos sociais, do acesso às instituições aos direitos garantidos por estas. Em relação às desigualdades econômicas, chamamos a atenção para o fato de que nem todas as pessoas que vivem nos países latino-americanos possuem poder de compra para usufruir dos bens pelo fato de não terem condições de pagar por eles. No que diz respeito às desigualdades culturais, é preciso sinalizar que as músicas, por exemplo, gozam de status culturais distintos. Isto significa dizer que as músicas europeias tendem a ter uma centralidade nos processos de educação musical, enquanto os fazeres e práticas musicais, assim como os repertórios que são oriundos das culturas populares e/ou originários tendem a ser mais marginalizados, sejam eles indígenas ou afro-diaspóricos, por exemplo.

Esta discussão coloca em evidência alguns marcadores importantes para a pesquisa que temos desenvolvido, cuja intenção é justamente compreender, por um lado, as práticas e os fazeres musicais e como estes se constituem em gêneros; e, por outro, investigar as maneiras de sua viabilização no ensino de música na Educação Básica. Outro elemento não menos importante que a pesquisa também diz respeito a compreender seus mecanismos de partilha de saberes, ou seja, quais seriam os modos os quais participantes das referidas práticas as ensinam e/ou aprendem.

Desta forma, falar sobre criação musical em experiências de educação musical no contexto latino-americano significa levar em conta as questões da colonialidade e seus desdobramentos; as desigualdades sociais, econômicas e culturais; e, por fim, a forte marca interseccional que aparece nos processos criativos desenvolvidos nas experiências com o ensino-aprendizagem de música.

Por tais questões apresentadas a partir do mosaico descrito anteriormente, compreendemos a importância de apresentar o conceito de pedagogias musicais abertas, que foi sendo formado no pensamento pedagógico musical latino-americano e quais as formas que a criação na educação musical assume dentro dessa concepção. 
Antes de mais nada, cabe ressaltar que não é possível pensar o ensino-aprendizagem de música na América Latina no singular, ou seja, como se existisse uma única maneira de conceituá-la e fazê-la. Até há elementos que aproximam os fazeres pedagógico-musicais dos diferentes países, mas

[...] não existe uma pedagogia musical latino-americana, e sim muitas! Somos muitos países, temos numerosas escolas de pensamento e ação e, acima de tudo, procuramos continuamente soluções criativas que respondam às necessidades específicas que nos são apresentadas em cada realidade geográfica, social e histórica². (MÉNDEZ, 2004, p. 7. Tradução nossa).

Considerando tais questões, este texto pretende apresentar um cenário sobre como é pensada a criação musical no contexto das pedagogias musicais abertas, trazendo um panorama sobre a temática sem, contudo, ter a pretensão de esgotá-la. Assim, na primeira parte traremos uma caracterização histórica e conceitual que apresentará o contexto no qual tais pedagogias foram sendo, aos poucos, forjadas. Cabe, neste sentido, sinalizar o marco da criação do Foro Latinoamericano de Educación Musical (FLADEM), como uma rede de professores de música de diversos países da América Latina, que foi, aos poucos, se tornando o espaço de debate sobre as pedagogias musicais abertas.

Na segunda seção, dissertaremos sobre a perspectiva de criatividade musical/criação musical dentro da concepção aqui apresentada, trazendo as ideias correntes sobre a temática e como estas foram, aos poucos, sendo evidenciadas à medida que o conceito de pedagogias musicais abertas foi sendo desenvolvido e amplificado, recorrendo principalmente a obras de Violeta Hemsy de Gainza, autora cuja obra foi dedicada grande parte sobre a temática, principalmente a partir dos anos 1980.

Na terceira parte refletiremos sobre a questão do tripé que compõe o percurso pedagógico-musical de professores de música (formação, atuação e avaliação) acerca das práticas criativas no ensino de música. Assim, relataremos que a defesa de alguns autores que serão mencionados é a de uma centralidade numa determinada ideia de música dentro do processo de formação, o que, a nosso ver, reverbera na prática pedagógica e na avaliação, ainda mais em se tratando da análise de processos criativos.

Por último, antes das considerações finais, apresentaremos propostas criativas das/nas pedagogias abertas, entendendo que estas são constitutivas do que Gainza (2013) chama de uma nova práxis de ensino de música³.

\footnotetext{
2. Original: "no existe una pedagogía musical latinoamericana, sino muchas! Somos muchos países, tenemos numerosas escuelas de pensamiento y acción, y sobre todo buscamos continuamente soluciones creativas que respondan a las necesidades específicas que se nos presentam en cada realidad geográfica, social, histórica".

3. É importante situar as ideias da autora temporalmente, sinalizando que esta "nova" práxis de ensino de música para a qual ela chama a atenção está circunscrita temporalmente ali pelo final dos anos 1980 e início dos anos 1990. Aliás, é preciso sinalizar que, em todos os momentos deste artigo nos quais mencionamos a "nova práxis de ensino de música" ou que ela chama de contemporaneidade, estamos tratando deste período, porém com reverberações até os dias atuais.
} 
Assim, apresentaremos o binômio participação e integração trazido pela autora como elemento-chave de uma prática pedagógico-musical aberta que propicie o desenvolvimento da criatividade. Em seguida, a partir de três eixos experiências musicais centradas na prática, práxis musical participativa e práxis musical integrada -, apresentaremos alguns exemplos práticos de atividades de autores diversos que têm criado propostas orientadas pelas pedagogias musicais abertas.

\section{Sobre as pedagogias musicais abertas}

Conceituar as pedagogias musicais abertas requer fazer um exercício histórico de busca sobre o pensamento pedagógico-musical latino-americano recente, dentro de um recorte específico da educação musical latino-americana que delinearemos mais adiante. Isso significa dizer que é necessário voltar no tempo, pelo menos até o começo da década de 1980, e fazer uma leitura atenta aos escritos da educadora musical argentina Violeta Hemsy de Gainza.

Gainza (2011) chama a atenção para o fato de que os métodos ativos na educação musical tiveram seus fazeres mais estimados nas décadas de 1960 e 1970 (p. 13). A questão é que, com os processos neoliberais e de globalização, estes métodos começaram a perder espaço para formas pedagógicas menos abertas à prática e à experimentação. Este processo gerou um movimento que fez com que se criasse uma convergência - opaca, em larga medida - na qual as práticas pedagógicas em música acabaram sendo, em alguma medida, homogeneizadas, por um lado, e homogeneizantes, por outro.

No primeiro caso, trata-se da materialização, perpetuação e cristalização das pedagogias geradas pela globalização e pelo neoliberalismo, ou seja, pedagogias que foram forjadas a partir de modelos educativos que se afastaram da realidade e da prática de sala de aula. A autora ainda afirma de forma contundente que há neste contexto um enfoque a uma prática pedagógica condutista, principalmente no campo das artes. No segundo, estas práticas contribuíram fortemente para a formação de sujeitos que estudavam e produziam música de uma forma pouco criativa, que não se utilizava de variados tipos de experimentação no processo de aprendizagem.

Brito (2012) chama a atenção para o fato de que uma das grandes preocupações de Violeta de Gainza é que a autora percebe que a educação musical começa ali pelos anos 1980 a construir uma espécie de lacuna presente entre a prática de ensinar música e reflexões sobre seu ensino. Isto fica evidente no forte caráter homogeneizado que passou a pautar as formas de se ensinar música.

Resumidamente, Gainza (2004) caracteriza então, em artigo publicado na Revista Musical Chilena, o século XX como o da iniciação musical: os anos 30 e 40 são chamados por ela de período dos métodos precursores; os anos 40 e 50 como o dos métodos ativos; os anos 50 e 60 como o dos métodos instrumentais; os anos 70 e 80 como o dos métodos criativos; os anos 80 e 90 como um período de transição e, por último, depois da década de 90 , como o período dos novos modelos pedagógicos. Poderíamos dizer que é neste período que começam a se solidificar os elementos marcadores das pedagogias musicais abertas.

Profundamente preocupada com os processos neoliberais de educação musical, principalmente nos anos 1980 e 1990, ela inicia um construto teórico-prático sobre práticas de educação musical que viessem a ser uma espécie de "caminho alternativo" frente aos modos homogeneizadores de se ensinar e aprender músi- 
ca. Fortemente influenciada pelo compositor canadense Raymond Murray Schafer, a partir de seus princípios criadores marcadamente experimentais que alargaram o sentido do fenômeno musical para uma atenção ao sonoro, a educadora musical argentina iniciou um movimento que culminou na criação do Fórum LatinoAmericano de Educação Musical, o FLADEM. Motivada por aquele compositor, ela o fez junto a outras educadoras musicais, como Carmem Méndez, da Costa Rica; Gloria Valencia, da Colômbia; e Margarita Fernández, do Chile. Logo neste momento inicial de criação do FLADEM também estava presente a educadora musical brasileira Marisa Fonterrada. Considerando os nomes citados, pensamos que não é um erro dizer que o FLADEM é uma instituição originalmente feminina.

O Fórum foi criado no ano de 1995 na cidade de San José, Costa Rica, e desde então tem buscado se fazer presente em variados países da América Latina, a partir da constituição das intituladas seções nacionais. O Brasil, como apontamos, está presente desde a fundação e já teve como representantes as professoras Teca Alencar de Brito e Adriana Rodrigues Didier. Esta última, em sua gestão buscou ampliar o raio de ação do Fórum em território nacional, o que foi amplamente aprimorado e estabelecido pelo último presidente da seção brasileira do FLADEM, o professor Leonardo Moraes Batista. Desta forma, o Fórum busca ampliar a reflexão e a prática das pedagogias musicais abertas, realizando anualmente os intitulados Seminarios Latinoamericanos de Educación Musical em distintos países.

Considerando que as pedagogias musicais abertas pretendem ser uma alternativa frente aos modelos fechados e preconcebidos de educação musical, Gainza (2002, p. 29, tradução nossa) sinaliza que

A abertura no pedagógico refere-se aos aspectos filosóficos da educação, mas também às técnicas educacionais. Envolve avaliação e análise da situação atual para, a partir daí, programar intervenções destinadas a promover processos de desenvolvimento ao longo dos diferentes ciclos da educação formal. A partir de uma ação de caráter global e aberto sobre a realidade, a qualquer momento será possível limitar os objetivos, "fechá-los" funcionalmente, para atingir um objetivo específico ${ }^{4}$.

No excerto acima, as palavras da autora são contundentes no que diz respeito a compreender as pedagogias musicais abertas em duas dimensões. Por um lado, é preciso entender que estas dizem respeito a uma perspectiva filosófica sobre ensinar música. Nesse sentido, cabe refletirmos que não é possível uma pedagogia aberta no ensino da música sem uma filosofia de educação que gere ancoragem para que o ensino seja diferente daquele que tenta homogeneizar.

4. Original: "La apertura en lo pedagógico remite a los aspectos filosóficos de la educación pero también a las técnicas educativas. Implica la evaluación y él y el análisis de la situación actual para, desde allí, programar intervenciones orientadas a promover procesos de desarrollo a lo largo de los diferentes ciclos de la educación formal. A partir de una acción de carácter global y abierto sobre la realidad, en cualquier momento será posible acotar en los objetivos, 'cerrarlo' funcionalmente, para el logro de un objetivo concreto". 
Assim, podemos afirmar que, para que haja mudança na ação de educar musicalmente, é necessária uma mudança de pensamento sobre a ação de ensinar música. Requer então um processo reflexivo que leva em conta as particularidades dos estudantes e, por outro lado, exige esforço político para que haja mudança da mente e da ação pedagógica. Apenas com a transformação da ideia de educação musical e de uma outra postura política é que será possível perceber uma materialidade que reflita uma mudança nas técnicas pedagógicas. As pedagogias musicais abertas requerem também mudança nas técnicas, nos modos de fazer educação musical.

Segundo Gainza (2013), o que ela chama de formas naturais de aprendizagem consiste na utilização de um conjunto de modelos que sejam completamente integrados, que possam ir desde o global ao particular e com isto tornando a aprendizagem ativa, porque aborda de forma direta o contato com a realidade. Assim sendo,

[...] os modelos pedagógicos musicais atuais devem focar na prática, além de integrar diferentes estilos musicais, incluir novas tecnologias, refletir gostos musicais, estudar diferentes formas de autoaprendizagem, interessar-se por pedagogias musicais abertas (GAINZA, 2013, p. 114, tradução nossa) ${ }^{5}$.

Todos os marcadores sinalizados pela autora, quando mesclados sem hierarquização, tendem a resultar em abordagens que irão ao encontro das pedagogias musicais abertas. Como ela coloca as ações no plural, isto leva-nos a compreender que não há uma forma de pensar pedagogia musical aberta, mas uma multiplicidade.

Nas palavras de Gainza (2002, p. 14), uma pedagogia aberta é sinônimo de tudo aquilo que é criativo, livre, experimental, como contraposto àquilo que é fixo, fechado, controlado, burocrático e pseudocientífico. Ainda segundo a autora, várias são as características de uma pedagogia musical aberta, porém gostaríamos de chamar atenção para um tópico em especial, como se observa a seguir:

A prática musical criativa, a experimentação, a descoberta pessoal e em grupo são as condições naturais de liberdade para crescer e se desenvolver. A criatividade é o ponto de partida e a meta, tanto em relação ao aluno quanto ao professor, com o processo e com as formas de ação pedagógica. (GAINZA, 2002, p. 14, tradução nossa) ${ }^{6}$.

5. Original: "Los modelos pedagógicos musicales actuales deberían centrarse en la práctica, además de integrar los diferentes estilos musicales, incluir las nuevas tecnologías, reflejar los gustos musicales, estudiar las diferentes formas de autoaprendizaje, interesarse en las pedagogías musicales abiertas".

6. Original: "La práctica musical creativa, la experimentación, el descubrimiento personal y grupal constituyen las condiciones naturales de la libertad para crecer y desarrollarse. La creatividad es punto de partida y meta, tanto en relación con el educando como con el maestro, con el proceso y las formas de la acción pedagógica". 
Tal perspectiva encontra eco nas palavras de Santos (2017, p. 483), autora que postula que

[...]uma pedagogia aberta se afasta do modelo da recognição. Vivemos a emergência da superação de tendências recognitivas e do determinismo que elas impõem. Uma pedagogia aberta é completamente oposta à recognição.

Isto significa dizer que, dentro das pedagogias musicais abertas, faz-se necessário sair da lógica que preconiza que é necessário repetir um modelo de tocar, cantar ou criar música. Dito de outra forma, é preciso ensaiar mecanismos para que saiamos de uma lógica reprodutivista ou condutista, conforme preocupação manifesta por Gainza (2011).

Segundo Sergio Balderrabano (2009), professor da Universidade Nacional de La Plata, na Argentina, entrar no âmbito de uma pedagogia aberta é ter como princípio que o trabalho docente será uma construção compartilhada, o que significa que é necessário fugir do lugar de poder que o professor possui em lógicas pedagógicas mais condutivas. Ele ainda indica que o objeto de trabalho deixa de ser a materialidade da obra musical em si, o que se repete em perspectivas pedagógicas mais tradicionais, tornando-se então o vínculo com o aluno o centro do trabalho do ensino musical.

Brito (2011), numa obra dedicada a Hans-Joachim Koellreutter ${ }^{7}$, corrobora com as palavras do autor supracitado, já que sinaliza que a importância da música e da arte só faz sentido na vida humana se for convertida em um instrumento de educação para que as pessoas possam se desenvolver em sociedade e em coletividade.

Ela também chama a atenção para o fato de que as pedagogias musicais abertas pretendem ser um espaço de atualização dos modos de pensar e fazer música nos territórios da educação musical, trazendo foco para as necessidades e questões próprias das culturas latino-americanas, como as questões que dizem respeito à identidade, assim como pensar as mais variadas formas que a criação musical pode assumir como instrumental pedagógico para o desenvolvimento musical, que, por sua vez, integra o humano (BRITO, 2019, p. 50). É principalmente nesta lógica que faz sentido falar em criação musical no contexto das pedagogias musicais abertas.

\section{A criação musical no contexto das pedagogias musicais abertas}

Assim como para compreender as pedagogias musicais abertas é preciso voltar um pouco no tempo, o mesmo podemos dizer a respeito da compreensão sobre a criação musical - ou a criatividade - dentro destas. Isso significa dizer

\footnotetext{
7. Hans-Joachim Koellreutter foi um músico, compositor, ensaísta e educador alemão radicado no Brasil, chegando ao país no ano de 1937. Criou o grupo Música Viva, no ano de 1939, tendo entre seus alunos nomes como Cláudio Santoro, Guerra-Peixe, Edino Krieger, dentre outros. Foi um dos fundadores da Orquestra Sinfônica Brasileira e também foi criador da Escola de Música da UFBA, no ano de 1954.
} 
que também necessitamos historicizar o conceito no contexto das perspectivas das pedagogias musicais latino-americanas.

Com isto explicitamos que, apesar de o conjunto de ideias que formam as pedagogias musicais abertas começar a ser apresentado publicamente e ter visibilidade a partir do final dos anos 80 e mais fortemente nos primeiros anos da década de 90, as concepções de criatividade ou de criação musical que as integram já estão presentes desde um pouco antes em outras publicações. Já que recorremos a Violeta Hemsy de Gainza para compreender o conceito de pedagogias musicais abertas, é também a partir dela que buscaremos compreender o conceito de criatividade e de criação musical dentro desta perspectiva.

A escolha por abordar a temática a partir da autora justifica-se pelo fato de que, dentro da epistemologia das pedagogias musicais abertas, é ela quem inaugura este debate e o traz a público em palestras, livros e artigos. Tanto que, posteriormente, trazemos para a conversa variados outros autores que dialogam com seu pensamento em suas perspectivas teóricas e em suas proposições pedagógico-musicais.

Dentre os mais variados assuntos abordados por Violeta em suas obras - tais como fundamentos, técnicas, formas de ensinar música -, o assunto da criatividade aparece em um livro de 1982 publicado originalmente em espanhol e intitulado Ocho estudios de psicopedagogia musical. Este livro foi traduzido para o português e lançado no ano de 1988.

Nele a autora discute que o conceito de criatividade não surge de forma improvisada na pedagogia moderna e, com isso, sinaliza que praticamente todos os métodos da primeira pedagogia musical do século XX preocuparam-se com o desenvolvimento da capacidade criadora. Ela ainda explicita preocupação com o fato de que as propostas pedagógicas em música deveriam criar liberdade para que o educando explore e descubra seus próprios modos de expressão, suas regras de jogo, de uso de materiais, de técnicas e de estilos. Ainda explana que, contudo, não deve ser necessária ou oportuna a abordagem de formas de criação pautadas em aspectos preestabelecidos.

Este debate sobre a reprodução/repetição e a respeito da importância do processo inventivo toma um caráter importante também dentro do debate empreendido por Fonterrada (2015). Segundo a autora,

[...] não se quer diminuir a importância da repetição e do conhecimento de repertório, essenciais ao desenvolvimento do aluno em relação à obtenção de capacidades específicas do instrumento. Não se consideram essas duas posturas - repetição e invenção - antagônicas, mas complementares. Se, por um lado, é necessário repetir para obter agilidade e respostas físicas apropriadas à condição de instrumentista e cantor, por outro, investir em atitudes de criação, iniciativa e liberdade de escolha são importantes fatores de domínio de determinadas habilidades, tão importantes quanto o domínio técnico-instrumental. Estacionar na repetição de modelos passados não caracteriza o pleno uso da linguagem, que prevê conhecimento técnico com autonomia de uso. (FONTERRADA, 2015, p. 226). 
Em consonância com esta autora, Gainza (1988, p. 107) sinaliza que a importância da experimentação com liberdade traz algumas vantagens:

[...] uma maior independência diante das formas tradicionais que não ficaram fixadas como referência inquestionável em todo ato de criação individual posterior; além disso, tantos os êxitos como as dificuldades do aluno desenvolverão seu julgamento apreciativo, podendo chegar assim a enfocar com naturalidade crítica o trabalho musical de outros [...].

A partir do excerto anterior fica explícito então que a concepção de criatividade da qual ela é tributária passa por uma dimensão de um duplo processo: para haver criação, é preciso o desenvolvimento de uma experiência auditiva, na qual o educando, ao mesmo tempo - e por outro lado -, pode construir elementos para manipular as fontes sonoras trazendo seus mecanismos de expressão. Ou seja, a escuta retroalimenta as formas de lidar com as materialidades sonoras, enriquecendo-as.

Certa vez, numa conversa com estudantes do curso de Musicoterapia da Universidade de Buenos Aires, Violeta foi questionada sobre ela já ter um modelo próprio de criatividade com o qual opera ou não. Ela explicou que ainda não havia escrito de forma específica sobre o assunto, com a qualidade e modéstia que thes são peculiares de não dizer algo sem ter estudado o suficiente, mas sinalizou que o conceito de criatividade com o qual ela opera é amplamente aberto (GAINZA, 2013, p. 165).

Essa concepção da qual a autora explica ser tributária significa que, no contexto das pedagogias musicais abertas, é preciso estar atento a tudo o que acontece, em termos de conceituação de criatividade e de práticas criativas, a tudo que é válido e que seja passível de decodificação. Não significa dizer que os jeitos de se pensar a criatividade no contexto das pedagogias musicais abertas atendem a modismos ou a fórmulas prontas que sejam vendidas como "receita de bolo" - até porque, se considerarmos que o ensino de música tem um caráter dinâmico e situacional, cada proposta de criação pode ser mais adaptável a um grupo de estudantes e não a outro.

Dentre as mais variadas fontes as quais a autora enuncia, ela comenta que

[...] existem modelos especializados em estimular a criatividade a partir da imaginação, da sensibilidade, do pensamento sensivel. Há outros que buscam promover a criatividade a partir da reflexão e sistematização; nos métodos de jazz; por exemplo, improvisação é o surgimento de uma prática concreta de diferentes tipos de escalas e acordes. (GAINZA, 2013, p. 165, tradução nossa). ${ }^{8}$

8. Original: "Hay modelos que están especializados en estimular la creatividad desde la imaginación, desde la sensibilidad, el pensamiento sensible. Hay otros que buscan promover la creatividad desde la reflexión y la sistematización; en los métodos de jazz; por ejemplo, la improvisación es el emergente de una práctica concreta de diferentes tipos de escalas y acordes". 
Contudo, Gainza (2013) sinaliza que tem explorado distintos meios e propostas para influenciar as formas criativas de estudantes em processos pedagógicos, como atividades que mobilizem desde 0 sensorial ou simplesmente a pura motricidade. Nesse sentido, ela chama atenção para o fato de que a criatividade no ensino da música, no âmbito das pedagogias abertas, depende de uma ação desde o ouvido, mas também da visão e da percepção do próprio corpo e do cérebro.

Gainza (2002, p. 66) traz uma importante síntese sobre os mecanismos ou os tipos de atividades que contribuem para a criatividade musical. Em sua perspectiva, os quatro princípios que orientam as práticas criativas são: o jogo, a descoberta, o movimento e a experiência. Assim, toda e qualquer atividade de criação musical que maneje uma dessas quatro áreas de forma integrada, ou seja, trabalhando de forma a relacionar uma atividade à outra e conectando-as a outros processos pedagógico-musicais, estará operando criativamente a partir das pedagogias musicais abertas.

Questionando sobre as dificuldades para introduzir na sala de aula as técnicas criativas de ensino de música, a autora faz um pequeno recorte histórico falando de variadas épocas de ensino de música no decorrer do século XX. A primeira época, denominada por ela como um tempo de revolução e mudança da "nova" pedagogia musical, que se estende até a primeira metade daquele século, trouxe como eixos do processo pedagógico os aspectos ativos dos estudantes. Já a segunda época, que tem sido dominada de revisão e atualização, trouxe foco à qualificação dos processos de criatividade. Neste momento, segundo a autora, ficam mais evidentes a influência dos trabalhos de George Self ${ }^{9}$ e Murray Schafer, por exemplo. A terceira época, dos anos 1980 em diante, para a autora é o período no qual se tende a reforçar a integração e a autonomia dos processos criativos na aprendizagem musical.

Tanto a temática da integração quanto a da autonomia têm se tornado pontos fortes de investigação e debate dentro das práticas criativas no campo das pedagogias musicais abertas. Os trabalhos de Adriana Didier $(2018,2020$ a, 2020b), atual presidenta do FLADEM, têm buscado mais recentemente centrar-se nesses dois aspectos, tentando compreender como a autonomia pode ser pensada de forma integrada aos processos de criação.

A pesquisa da autora tem alargado o campo das pedagogias musicais abertas, voltando, mais recentemente, sua atenção para entender como estas pedagogias e as formas de pensar as perspectivas criativas podem colaborar com o desenvolvimento de aspectos que são importantes para o humano e sua formação cidadã, ou seja, para além de uma formação musical descolada da realidade das formas de fazer música inventivamente. Neste sentido, seu trabalho se coaduna a outras lógicas de educação musical que estão preocupadas com os processos pedagógico-musicais. Por outro lado, estas formas têm se atentado de modo assertivo a entender como as

\footnotetext{
9. Músico inglês comprometido com a música e com uma educação musical de vanguarda. Assim, para ele, o ensino de música a partir de um repertório e formas do passado limitava a criatividade do aluno, o que levava a reproduzir uma forma repetitiva e "adestrada" de aprender e fazer música. Assim, o modelo de educação musical proposto por Self visava preparar o aluno para a escuta da música da contemporaneidade e para as criações feitas pelos próprios estudantes, assim como a estimular a criatividade e a invenção.
} 
pedagogias musicais abertas precisam produzir modos de pensar o ensino de música para além dela mesma, ou seja, debatendo aspectos que, por exemplo, dizem respeito à formação humana (BRITO, 2011, 2015) ou a uma educação musical antirracista (BATISTA, 2018a, 2018b), dentre outros aspectos.

Inscrita nesta perspectiva mais contemporânea das pedagogias musicais abertas, em recente pesquisa Didier (2020b) fez uma arqueologia do conceito da expressão criadora e de como esta concepção, juntamente com o debate sobre a autonomia, promoveu uma circularidade de ideias dentro do pensamento pedagógico no campo das artes na América Latina no decorrer do século XX, especialmente da década de 70 em diante. Conforme a autora sinaliza, a ideia inicial da expressão criadora foi desenvolvida pelo educador uruguaio Jesualdo Sosa, que, numa de suas obras, buscou compreender como se dá o seu desenvolvimento nas crianças pequenas. Já em relação ao conceito de autonomia, a autora é tributária do pensamento do pensador brasileiro Paulo Freire.

Ela caracteriza sua pesquisa como uma análise documental, já que analisa diversos documentos que datam do referido período e mostram a troca de ideias sobre diversos professores de variados países da América Latina, principalmente Brasil e Uruguai. Ela postula que é graças à circularidade que este movimento pôde ser instaurado, e isto possibilita a existência de um pensamento brasileiro com reflexo na América Latina. No Brasil, isso se deu com a Escolinha de Arte do Brasil e, na contemporaneidade, com o FLADEM.

Didier (2020b) traz uma correlação importante entre expressão criadora e autonomia, já que em sua percepção não há o desenvolvimento da primeira se não houver movimento político de consciência da segunda. Dito de outra forma, toda e qualquer pessoa em situação de aprendizagem apenas consegue expressar-se livremente e apresentar suas ideias musicais, de forma criativa, se no processo pedagógico houver uma explícita intenção docente de desenvolver este valor como algo inerente ao desenvolvimento da formação humana dentro do contexto pedagógico-musical.

Por fim, pensamos ser importante comentar que o debate sobre as práticas criativas no âmbito das pedagogias musicais abertas sempre trouxe um debate amplamente ideológico, no qual a ideologia em questão é a promoção da autonomia como valor para a independência do educando no que diz respeito à sua expressão criadora. Contemporaneamente essas questões têm se tornado bastante centrais nos debates desenvolvidos no âmbito do Fórum Latino-Americano de Educação Musical, instituição da qual tem emanado a articulação teórico-prática sobre a criação musical dentro dessas pedagogias.

\section{O tripé formação/atuação/avaliação docente e as práticas criativas no contexto das pedagogias musicais abertas}

Segundo Patricia Stokoe (1997), criadora e impulsionadora da expressão corporal na Argentina e que trabalhou muito proximamente à Violeta de Gainza, é preciso, no contexto das pedagogias musicais abertas, o desaparecimento da imagem daquele educador que "deve saber tudo" para dar passagem ao educador preparado para promover os processos criativos. Neste sentido, ela comenta que não se trata de ensinar a capacidade de criar, mas de criar condições para que o aluno empreen- 
da seu próprio caminho, faça suas próprias conexões e desperte para o seu próprio processo criativo (STOKOE, 1997, p. 58). Por fim, discorre que é importante que o professor, por si mesmo, assuma o seu próprio processo criativo.

Caminhando nessa direção, pensamos ser importante trazer a contribuição do debate sobre a formação para a criação e para a interpretação musical, trazido pelo compositor e musicólogo uruguaio Coriún Aharonián. Há um especial interesse por parte do autor sobre o processo de formação do músico, em como ele se dá, se por uma via institucional ou se por uma via mais informal. Apesar de estar falando em grande parte do ensino de composição, ele também chama atenção para o fato de que a forma influencia o ensino de música, ou seja, se aquelas cujas fontes são as formas da música erudita ou da música popular.

Aharonián (2013) faz uma severa crítica sobre os currículos de música no ensino básico que são institucionalizados massivamente na América Latina de forma a cristalizar determinada ideia de música e de musicologia. Para este autor, em todos os níveis de ensino, inclusive no superior, é possível observar em diferentes países e regiões uma enorme pluralidade musical popular, e a educação formal tende a ignorar e a promover um empobrecimento da musicalidade potencial tanto das crianças quanto dos músicos em sua formação inicial, por conta do uso desmesurado de metodologias europeias. Neste contexto, um estudante se torna culto

[...] quando aprende história e geografia europeias enquanto continua a ignorar o que foram Artigas $^{10}$ ou Morelos ${ }^{11}$ o Sucre 12 onde estão Vaupés, ou Paraná, ou a Serra Nevada de Santa Marta e Chiapas, ou a llha de Marajó ou o Lago de Pátzcuaro. ${ }^{13}$ (AHARONIÁN, 2013, p. 59).

Aharonián (2013) traz este exemplo sobre personalidades e lugares que são de países da América Latina e que, por vezes, sequer temos conhecimento para demonstrar o quanto ainda em nossas práticas curriculares e nos nossos estilos de ensinar e aprender ainda somos reprodutores de uma lógica europeia, enquanto, por outro lado, sequer conhecemos elementos de nossa identidade latino-americana. Isto significa dizer que conhecemos pouco das músicas de origem popular, assim como das formas de ensinar e aprender oriundas desses territórios.

Nas palavras de Vincenzi (2009), há que se ter um cuidado, já que o sistema procura sempre se reformular com vistas a reproduzir algum tipo de colonialismo que tenta silenciar as identidades culturais latino-americanas. Neste sentido, nossa identidade cultural-pedagógico-musical-criativa, que está fortemente presente nos jeitos de fazer música nas culturas populares e também em nossas práticas pedagógicas, pode tender a sofrer uma espécie de neocolonização.

10. José Gervasio Artigas foi um político e militar uruguaio, tido como herói deste país.

11. José María Teclo Morelos y Pavón foi um dos mais importantes líderes na independência do México.

12. Antonio Jose de Sucre foi um estadista venezuelano, considerado herói da independência hispânica.

13. Original: "[...] cuando aprende la historia y la geografía europea mientras sigue ignorando quieres fueron artigas o Morelos los sucre y dónde quedan el Vaupés o el Paraná o la Sierra Nevada de Santa Marta y Chiapas o la isla de Marajó o el lago de Pátzcuaro". 
Pensando um pouco sobre uma segunda dimensão, a da atuação pedagógica de professores de música pautada nas práticas criativas, entendemos ser de fundamental importância trazer a pesquisa da professora Marisa Fonterrada (2015), que observou que no Brasil elas ainda são um tanto quanto tímidas. Numa grande pesquisa feita com educadores brasileiros, ela percebeu que, "seja esta ministrada em conservatórios, escolas de Música, universidades ou em projetos sociais e culturais, o trabalho de caráter criativo tem sido escassamente encontrado" (p. 15-16). Segundo a autora, outras áreas do campo da Arte, como as Artes Visuais e o Teatro, possuem alguma trajetória acerca das práticas criativas nas atividades de ensino. Muito embora circunscrita ao território brasileiro, sua pesquisa pode indicar alguns caminhos relevantes para uma sinalização de que ainda há uma ausência profunda sobre o estudo de práticas criativas no ensino de música na América Latina, algo que foi de alguma forma insinuado por Aharonián (2013).

No texto da autora há a presença de dois quadros que sintetizam as respostas dadas ao questionário que foi feito com os participantes da pesquisa. O primeiro (FONTERRADA, 2015, p. 200) traz as respostas dos entrevistados sobre quais seriam os autores brasileiros de referência para suas práticas criativas. Entre os nomes mais citados, estão o do compositor e educador musical Hans-Joachim Koellreutter e o da educadora musical Teca Alencar de Brito, sendo o primeiro citado por 18 entrevistados e a segunda por 14. Já no quadro que traz as respostas sobre autores estrangeiros (FONTERRADA, 2015, p. 202), há a presença de quatro educadores musicais homens (R. Murray Schafer, Keith Swanwick, Emile Jaques-Dalcroze, Carl Orff) e norte-americanos ou europeus, e em quinto lugar a presença da educadora Violeta Hemsy de Gainza.

O fato de os educadores musicais brasileiros mais citados serem os nomes de Koellreutter e Brito traz algum indício de que as ideias sobre as pedagogias musicais abertas têm encontrado eco nas práticas pedagógicas criativas de professores do Brasil, já que Teca Alencar de Brito é abertamente uma tributária delas e tem produzido obras tendo esta perspectiva como ponto de inflexão (BRITO, 2003) e, mais recentemente, de forma mais explícita, tem desenvolvido ideias de tais pedagogias em seus textos (BRITO, 2012, 2019).

O fato de Violeta de Gainza - uma das precursoras do pensamento das pedagogias musicais abertas no contexto pedagógico-musical latino-americano - estar numa posição um pouco mais abaixo na lista de autores estrangeiros que fundamentam a prática pedagógica dos professores entrevistados por Fonterrada (2015) coloca-nos num lugar de interrogação sobre o que - e o quanto - ainda precisamos fazer para que as pedagogias musicais latino-americanas, especialmente as pedagogias musicais abertas, ocupem um lugar de relevância na filosofia e na prática de professores de música no Brasil.

Por fim, a terceira dimensão, que possui extrema relevância para pensar sobre o professor e as práticas criativas no contexto das pedagogias musicais abertas, diz respeito à avaliação. Esta, em variadas práticas pedagógicas, ainda possui forte caráter mensurador ou disciplinador, seja em atividades pedagógicas formais na escola ou fora dela. Na avaliação de Libâneo (2017), o instrumento prova que ainda continua sendo mormente utilizado como um mecanismo de verificação das atividades propostas independentemente da natureza destas. Se ela é utilizada para legitimar o medo ou criar qualquer situação de intimidação 
- o que infelizmente ainda é muito comum -, nas palavras de Luckesi (2011), ela perde o seu contexto de instrumento avaliativo e torna-se um instrumento de controle social.

A avaliação da aprendizagem dos/nos processos criativos em música está bastante distante das perspectivas as quais os autores criticam. No pensamento de Beineke $(2011,2012,2015)$, que tem centrado os seus estudos a partir da aprendizagem criativa, há que se ter um processo de avaliação que decentralize essa função apenas como algo a ser desempenhado pelo professor. Segundo a autora, é preciso que se incentive a participação colaborativa e a coparticipação na avaliação, já que, "quando essas experiências são discutidas e avaliadas pela turma, nos momentos de apresentação e análise das composições" (BEINEKE, 2011, p. 101), os estudantes se sentem partícipes, de fato, das atividades propostas. Algo imprescindível de ser sinalizado nesse processo colaborativo é o fato de que não há a intenção de estabelecer uma comparação para que se perceba o nível de criatividade musical (BEINEKE, 2011).

Avançando no debate sobre a lógica colaborativa e coparticipativa, Beineke (2018) chama a atenção para como se dá entre as crianças o jogo que estabelece os critérios que serão levados em conta em cada grupo. Assim, a autora traz a ideia de avaliação intersubjetiva, pontuando que tais critérios musicais de avaliação da criação musical são produzidos no seio de cada grupo de estudantes. Este critério/forma de avaliação considera que "o trabalho em grupo exige o estabelecimento de trocas intersubjetivas que favoreçam novas combinações de ideias e sugestões imaginativas" (BEINEKE, 2018, p. 160). Desta forma, os intercâmbios produzidos nas relações tecidas entre os estudantes oportunizam a emersão de outras práticas criativo-musicais, para as quais inclusive já haverá critérios de crítica que foram forjados pelo próprio grupo. Algo para o qual a autora chama a atenção é a necessidade de entendimento nesses espaços intersubjetivos, já que é preciso compreender que este "não significa adesão cega à ideia do outro ou submissão ao discurso hegemônico e legitimador, mas um princípio central no estabelecimento de solidariedade, de interação e de socialização" (BEINEKE, 2018, p. 161).

No prisma das pedagogias musicais abertas, a avaliação da criação musical assume um caráter bastante crítico às concepções e formas de avaliação que costumam centrar-se numa abordagem puramente cognitiva. Segundo Gainza (2010), os professores precisam primeiramente passar por um processo de autoavaliação sobre a temática da cognição para posteriormente pensar sobre a avaliação dos processos de criação musical dos estudantes. Para a autora, é imprescindível sair do "modelo", que ainda é pautado num pensamento sobre cognição que não abre margem para a autonomia e para pensar nos processos, já que, por sua vez, tende a reproduzir uma lógica conservatorial da reprodução como sinônimo de criação.

É preciso entender também que, dentro das pedagogias musicais abertas, a avaliação precisa ser considerada como uma atividade de aprendizagem (MORANDIN; EYMANN; SHAPIRO, 2009), na qual o professor consegue, aos poucos, ir aprendendo a conhecer mais para que possa aprimorar seu fazer pedagógico e, assim, conseguir compreender as dificuldades que precisa superar em si mesmo e aquelas que possivelmente emerjam das diferentes configurações das turmas para as quais ministra aulas de música. 
Para ampliar o debate sobre avaliação das práticas musicais nas pedagogias musicais abertas, é preciso ainda pensar nas práticas curriculares e em como estas apenas reproduzem ou criam mecanismos autônomos de avaliação. Para Gainza (2011, p. 17), "o modelo curricular não tem favorecido o mencionado destaque do educando nem o exercício da autonomia e do bom senso por parte do professor". Como alternativa a este modelo curricular, podemos trazer duas ponderações.

A primeira diz respeito às etapas do processo pedagógico nas pedagogias musicais abertas e de como se pensa a avaliação: "escolher, compartilhar, elaborar, registrar, preservar [...] experiências, [como] algo humano, musical, natural" (GAINZA, 2010, p. 34, tradução nossa. Os grifos também são nossos) ${ }^{14}$. Cremos que as ações em destaque são de fundamental importância para os processos de aprendizagem atravessados por práticas criativas. Cabe sinalizar que, no pensamento da autora, o compartilhamento de práticas e de formas de criar são de fundamental importância para que os educandos possam se desenvolver criativamente. O registro aparece como forma de uma busca por materializar os compartilhamentos feitos, sejam registros gravados, escritos ou filmados. Estes podem auxiliar como mecanismo para preservação das formas como os estudantes fazem e falam sobre seus processos e obras e, por outro lado, servem como uma espécie de portfólio para ações futuras de avaliação do desenvolvimento criativo-musical dos educandos.

A segunda diz respeito aos critérios de avaliação do contexto das pedagogias musicais abertas que, conforme López León (2015), devem ter correspondência com o contexto dos alunos para que, só assim, se faça uma boa seleção de conteúdos musicais mais acertados para o propósito da criação. O autor amplia o raio de referência dos critérios de avaliação, comentando que podemos

[...] considerar as situações, conflitos, necessidades e características da sociedade que os cerca em seu processo pedagógico por meio da discussão, comunicação de ideias, sensações, diálogos abertos e debates produtivos críticos (LEÓN, 2015, p. 81) ${ }^{15}$.

De forma sintética, podemos afirmar que a avaliação dos processos de criação musical precisa se dar de forma processual, participativa e compartilhada. A autonomia é um dos pilares mais preponderantes das pedagogias musicais abertas, porque por intermédio dela se pode criar situações nas quais os alunos possam falar do seu fazer criativo musical e o registrarem para posterior apreciação. Ela torna-se mecanismo importante para, inclusive, pensar os critérios que serão levados em conta na avaliação tanto por parte do professor quanto por parte dos alunos.

14. Original: "Escoger, compartir, elaborar, registrar, conservar [...] experiencias, [como] algo humano, musical, natural".

15. Original: "considerar las situaciones, los conflictos, las necesidades y las características de la sociedad que los rodea en su proceso pedagógico a través de la discusión, la comunicación de ideas, las sensaciones, los diálogos abiertos y los debates críticos productivos". 


\section{Sobre atividades criativas dentro (e a partir) das pedagogias musicais abertas}

Entendemos ser fundamental trazer à baila dois aspectos que Gainza (2013) traz como elementos constitutivos de uma nova práxis de ensino de música, com vistas a entender as atividades criativas: a participação e a integração. Para ela, estes são elementos-chave de uma prática pedagógico-musical aberta que propicie a criatividade.

As caracterizações que a autora faz acerca deste binômio trazem perspectivas que colocam em jogo uma atuação pedagógica pautada no debate sobre as práticas criativas. Neste sentido, ela sinaliza que o novo paradigma que vem sendo construído na contemporaneidade (GAINZA, 2013, p. 71) traz consigo um conjunto de princípios pedagógicos que apresenta uma multiplicidade de práticas que giram em torno de três eixos: o de que as experiências precisam estar centradas na prática; a de que toda práxis musical deve ser participativa, por um lado, e integrada, por outro.

Com base nestes eixos propostos por Gainza (2013, p. 141-143), ensaiamos propor uma sistematização de princípios e ações criativas forjadas por ela própria e por outros autores que trabalham com perspectivas criativas a partir de seus escritos sobre as pedagogias musicais abertas. Esta organização apresentada serve apenas como um critério para facilitar a compreensão dos princípios (e) das práticas criativas decorrentes das pedagogias musicais abertas. Não se trata de dizer que cada dimensão é independente da outra e que as práticas não se intercambiam, a ponto de uma que está na primeira seção não poder estar na segunda, por exemplo. Temos consciência de que, como afirma a autora (GAINZA, 2013, p. 143), toda prática de criação musical deve ser desenvolvida de forma integrada.

\section{Experiências centradas na prática}

Para Gainza (2013, p. 142), "a música se aprende 'fazendo' música", 16 ou seja, em seu entendimento, o aprendizado musical só acontece de fato quando o estudante manipula de forma ativa as materialidades musicais e/ou sonoras. Neste sentido, é possível afirmar que não se aprende a criar musicalmente apenas falando sobre criação. Não há, nesta acepção, sentido para a criação se crianças, adolescentes e/ou adultos não fizerem música para aprender sobre as formas de organizar sistematicamente o material sonoro. Assim, torna-se uma premissa das pedagogias musicais abertas, mas não exclusivamente delas (FRANÇA; SWANWICK, 2002; SWANWICK, 2003; BEINEKE, 2011, 2012, 2015, 2018), lidar com a criação musical criando.

Com este horizonte, poderíamos expressar que todas aquelas atividades que manipulam o sonoro com vistas a pensar sobre os processos de organização podem ser consideradas como pedagogias musicais abertas. Porém esta assertiva só pode ser corroborada se estas também, por sua vez, colocarem em suas práticas a primazia nos processos internos do educando antes de qualquer interesse de coletar algum dado do estudante. Outra forma seria a prática de tais atividades

16. Original: "la música se aprende 'haciendo' música". 
serem avançadas quando houver uma percepção de que os estudantes já sistematizaram a informação (GAINZA, 2002, p. 14) ou já demonstraram dominar o processo de criação com a manipulação dos materiais sonoros, seja numa situação individual (se for um ensino individual) ou grupal.

Mas há um ponto interessante que chama a atenção. Na concepção de Gainza (2002), a criatividade toma corpo e se solidifica quando as experiências concentradas na prática criam uma correlação com o movimento, a visão, o tato e o ouvido. Há então, na visão da autora, uma forte relação entre a prática de criação musical e a relação com outros elementos sensoriais que estimulem o espírito criativo.

A manipulação e a construção de instrumentos musicais com materiais diversos, combinando materiais oriundos da natureza ou de outras fontes, testando sonoridades e observando, escutando e executando as combinações possíveis, podem ser um exemplo de uma experiência centrada na prática do fazer musical, conforme expõem Brito (2003) e Sardo (2019). Este último autor aposta num manuseio de "matéria-prima não convencional e nativa" (SARDO, 2019, p. 155). Como o autor é brasileiro, os materiais presentes em seu processo criativo de investigação sonora são a cabaça e o bambu, por exemplo. Mas, se considerarmos que cada país da América Latina possui materialidades próprias, é possível entender que elas podem (e precisam) estar presentes nos processos investigativos de criação para reforçar o caráter da presentificação da identidade latino-americana na investigação sonora.

Brito (2003) narra que a sonorização de histórias também pode ser elemento de fundamental importância para o processo criativo, principalmente na infância, que é o estágio de ensino de música a que ela se refere na obra em questão. Em sua leitura, os processos de sonorização de histórias estimulam a "capacidade inventiva, desenvolvem o contato e a vivência com a linguagem oral e ampliam recursos que incluem o vocabulário, as intenções expressivas, as articulações, enfim, a musicalidade própria da fala" (p. 161).

Algo interessante de ressaltar é que, neste processo de experimentar combinações sonoras a partir da construção de instrumentos e da criação de histórias, não se pode perder de vista a relação com a cultura (BRITO, 2003, p. 71). Isto nos leva a pensar que, nestes processos, os educandos trilham caminhos e fazem procedimentos, ora repetindo alguns traçados por nós, ora criando outros. Neste sentido, entendemos ser fundamental trazer um ponto para o qual Vincenzi (2009) chama a atenção: o quão colonizador pode ser este percurso. Para o autor, é importante que, nestes processos de descoberta, se possa afirmar nossa identidade cultural latino-americana. Assim, é imprescindível observar que se corre o risco de um duplo - e até cumulativo - processo colonizador. De um lado, pode-se incorrer na possibilidade de reiterar mecanismos colonizadores, conservatoriais e eurocêntricos acerca das formas de lidar com o sonoro. Por outro, uma colonização do saber do estudante, na qual o professor pode tender a não dar margem para que ele possa trilhar seus próprios percursos de investigação criativa. Há modos de manipular o sonoro no território latino-americano que nos são muito peculiares e, dentro de uma perspectiva aberta de pedagogia musical, estes modos têm vez e força criativa. 


\section{Práxis musical participativa}

Dentro do âmbito das pedagogias musicais abertas, algo que se faz bastante presente é a noção de que a música precisa ser um fazer coletivo. Isso significa dizer que, na nova práxis de ensino de música proposta por Gainza (2013), a partir dos novos paradigmas trazidos pelas pedagogias musicais abertas, há que se ter como forma de criação musical um fazer que integre os diferentes atores do processo pedagógico. Com isso, as práticas criativas no ensino de música buscam materializar jeitos e fazeres que façam mais sentido quando produzidos coletivamente e em colaboração.

Assim, pensamos ser interessante caracterizar três práticas de criação musical que podem integrar práxis musicais participativas no contexto das pedagogias abertas: a interpretação, a improvisação e a composição, tomando como base a argumentação desenvolvida por Brito (2003). Nas palavras da autora, "a interpretação é a atividade ligada à imitação e reprodução da obra. Mas interpretar significa ir além da imitação por meio da ação expressiva do intérprete. Somos intérpretes quando cantamos ou tocamos uma obra musical" (BRITO, 2003, p. 57). Fica explícito em suas palavras que há na interpretação - mesmo tendo um caráter imitativo - algo de situacional que acontece no processo de construção da reprodução de determinada obra. Assim, é possível afirmar que há, na interpretação, também algo de criação musical. É relevante sinalizar que, neste processo feito num contexto pedagógico, o intérprete sempre recebe contribuições e críticas de outros colegas sobre as escolhas feitas para a execução de determinada peça musical. Esta "colaboração interpretativa" se amplia quando a obra é planejada para ser executada coletivamente, o que quer dizer que, além da contribuição externa, há um processo de construção desta interpretação feito pelo coletivo que vai executá-la dentro da própria turma.

Já a improvisação consiste em

[...] criar instantaneamente orientando-se por alguns critérios. [...]. Quando improvisa, o músico orienta-se por critérios e referenciais prévios, e, tal qual acontece na fala improvisada, quando coisas interessantes e significativas são ditas sem que fiquem registradas, a improvisação musical lança ideias, pensamentos, frases, textos... (BRITO, 2003, p. 57).

Numa obra de Gainza (1983) que trata especificamente sobre o aspecto da improvisação como gesto criativo, a autora caracteriza esta forma de criação musical como uma

[...] execução sonora instantânea produzida por um indivíduo ou grupo de indivíduos variando de total liberdade à sujeição a diretrizes rígidas, desde a situação espontânea até a participação da consciência mental. (GAINZA, 1983, p. 11). ${ }^{17}$

17. Original: "[...] ejecución sonora instantánea producida por un individuo o grupo de individuos que abarca desde la libertad total, hasta la sujeción a pautas estrictas, desde la situación espontánea hasta la participación de la conciencia mental". 
Nesse sentido, fica explícito em suas palavras que a improvisação pode assumir um caráter muito variado como proposta criativa no ensino da música. É possível que seja encarada numa linha que esteja mais próxima à expressão mais livre ou, por outro lado, pode atender a determinadas formas que se alinhem a determinados contornos postos à criação.

Comentando as ideias da autora, Brito (2003, p. 151) assinala que para ela "a improvisação é uma forma de jogo-atividade-exercício que permite projetar e absorver elementos ou alimentos musicais numa constante retroalimentação", onde a escuta, a manipulação sonora e uma esfera lúdica estejam sempre presentes. Citando o pensamento de H. J. Koellreutter, a autora assinala que "a improvisação deve ser o principal condutor das atividades pedagógico-musicais" (BRITO, 2003, p. 152).

Cremos, a partir desta premissa, que a atividade de improvisação toma outro fôlego e força o processo criativo dentro das pedagogias musicais abertas quando opera numa lógica de produção coletiva. Isto quer dizer que, num contexto de processos de experimentação, a improvisação tende a despertar outros sentidos quando feita em conjunto. O exercício improvisativo frente a um grupo de indivíduos direciona a audição para o aspecto da coletividade do trabalho que está sendo executado, já que os alunos escutam os processos de improvisação uns dos outros. Neste sentido, os processos feitos coletivamente assumem um caráter pedagógico mais relevante do que aqueles que são feitos individualmente, e grande parte das proposições de exercícios de improvisação passa por uma lógica de coletividade.

Dentro de diferentes perspectivas de exercícios de improvisação, há uma tendência explícita para o fato de que experiências improvisativas coletivas tendem a reforçar o caráter auditivo, considerando que este é o motor importante no processo de criação. Tal premissa é bastante presente naquelas propostas de exercícios nas quais se centram os trabalhos de diferentes autores (GAINZA, 1983; BRITO, 2003, 2019; LINO; DORNELLES, 2019). Há nestes um especial valor na improvisação como lugar de encontro de multiplicidades - de sons, de formas de lidar com o sonoro -, já que

[...] a improvisação interpela a escuta, que vagueia na tentativa vã de apreender a unicidade de cada parte. A improvisação é, pois, um exercício libertário que ensina o corpo a fazer, desenclausurando a compreensão sensível do mundo porque ato poético. (LINO; DORNELLES, 2019, p. 168). 


\section{Práxis musical integrada}

Em relação à práxis musical integrada, no que diz respeito às práticas criativas no contexto das pedagogias abertas, Gainza (2013, p. 143) chama a atenção para o fato de que,

[...] do ponto de vista musical (do objeto de conhecimento), toda prática ou experiência musical deve ser integrada, condição ou qualidade que remete à inclusão - livremente arranjada - de alguns dos aspectos musicais básicos inerentes às diferentes práticas. ${ }^{18}$

Para a pedagoga argentina, há que se ter integração em pelo menos quatro grupos de atividades nas quais os aspectos criativos podem e devem ser aprofundados: o primeiro, do desenvolvimento da linguagem musical, onde circula a relação da criação com o canto do repertório desenvolvido; o segundo, daquelas atividades criativas que contribuem para o desenvolvimento auditivo; o terceiro centra-se nas atividades de improvisação e composição a partir de uma perspectiva integrada; o quarto, de forma mais global, busca estabelecer como os aspectos criativos podem ser desenvolvidos em atividades de análise estrutural de obras (criadas pelo grupo de estudantes), trazendo diferentes formas de observá-las. Como já trouxemos algumas reflexões acerca das atividades de improvisação e composição no item anterior, discorreremos algumas ideias e práticas acerca dos outros três grupos descritos pela autora.

No que diz respeito às práticas criativas que lidam com o canto, é preciso sinalizar que o ato de cantar possui grande preponderância nas práticas pedagógicas que lidam com experiências criativas. Isso significa dizer que, desde uma canção mais simples até uma mais complexa, oriunda das culturas populares ou das "paradas de sucesso", o canto representa uma esfera importante do processo pedagógico-musical. Neste sentido, cabe explicitar algumas abordagens que têm lidado com práticas vocais de forma variada em contextos pedagógicos de forma criativa a partir do prisma das pedagogias abertas.

Em um significativo trabalho no qual explicita elementos teóricos e práticos para a música na educação infantil, Brito (2003) traz um relevante debate sobre as práticas vocais com as crianças. A autora explica que a voz é o primeiro instrumento que pode ser utilizado e de diversas maneiras. Assim sendo, ela sinaliza que o trabalho vocal pode e precisa, a partir de um processo de experimentação, onde se possa brincar com a voz, experimentar quais são as possibilidades de realização vocal. Desta forma, não só traz várias sugestões de atividades, como também sugere princípios para a escolha do repertório. Neste quesito, traz algumas sugestões a respeito "da adequação da melodia, do ritmo, da letra e da extensão vocal" (BRITO, 2003, p. 94), algo que é de extrema importância para que a criança possa executar a música de forma adequada. Ressalta ainda o valor que tem o uso de canções oriundas da cultura popular, incluindo a possibilidade de uso de repertórios de outros países. Isto traz

18. Original: "desde un punto de vista musical (del objeto del conocimiento) toda práctica o experiencia musical debería ser integrada, condición o cualidad que remite a la inclusión - libremente concertada - de algunos de los aspectos musicales básicos inherentes a las diferentes prácticas". 
uma dimensão importante para o trabalho, já que, do ponto de vista da linguagem, as crianças que estão com algo mais sistematizado do seu idioma materno poderão experimentar outros jeitos de sonorizar com a voz. Assim, cantar em espanhol ou guarani, por exemplo, pode tornar-se um exercício vocal para além daqueles sons oriundos de palavras já conhecidas.

O trabalho com a canção desenvolvido pela peruana Luzmila Mendivil (2017, p. 96) traz uma dimensão crítica e política para o debate sobre seus usos, entendendo que "as canções são atos comunicativos que promovem várias interações, tanto nos professores como nas crianças". Em sua perspectiva, cantar canções em grupo é uma prática social que se caracteriza por várias conexões linguísticas e interações corporais. Assim, para a autora, a voz, a palavra cantada e o gesto convocam a criação de uma forma discursiva de outra ordem. Mais uma vez percebe-se aqui uma abordagem integrada de práticas vocais no contexto das pedagogias musicais abertas.

No decorrer de sua pesquisa, algo que chamou sua atenção foi o fato de que, infelizmente, as canções são empregadas como mecanismo de controle simbólico para reforçar algumas relações de poder, principalmente aquelas que dizem respeito aos papéis comumente desempenhados pelo professor e pelo aluno. Neste sentido, a autora traz uma crítica a este uso da canção, já que, em seu contexto de pesquisa, a saber, os anos iniciais de escolas públicas do Peru, há um uso que não se coaduna com os princípios das pedagogias musicais abertas. A autora critica severamente esta abordagem das canções, defendendo que elas precisam passar por um amplo trabalho de seleção para que possam ter seu objetivo de elemento propulsor da criação alcançado.

Numa direção próxima, cabe ressaltar também o trabalho de Didier (2017), que tem centrado seus trabalhos mais recentemente em um debate sobre as possibilidades criativas com a voz. Assim, uma de suas propostas, chamada por ela de "língua maluca",

[...] apesar de não possuir um significado intrínseco, sua mistura de sons sugere o sentido do discurso. Trata-se, portanto, de um jogo onomatopeico, articulado com arbitrariedade, mas capaz de transmitir, com o acréscimo de gestos, ritmos e sonoridades particulares, um discurso completo. (DIDIER, 2017, p. 3).

A partir do fato de ela atentar-se para a importância do uso de gestos, de ritmos, de sonoridades diversas e de como essa variedade de usos pode propiciar um discurso completo, percebemos que há, como pano de fundo da proposta, uma vontade de operar o uso da voz de forma integrada a outras formas criativas. Por fim, ela comenta que, depois de ter forjado e experimentado a proposta, tomou conhecimento de que há uma técnica bastante utilizada principalmente no teatro, que lida com a voz desta forma, intitulada de Grammelot, que é "uma linguagem inventada nos séculos $X V$ e $X V I$, sequência de sons aparentemente sem sentido, mas totalmente onomatopaicos (ou que imitam línguas estrangeiras) e alusivos na cadência e nas inflexões" (DIDIER, 2017, p. 3).

Outra proposta de sua autoria recém-publicada traz boas sugestões de uma possibilidade com a boca (DIDIER, 2019), mas não necessariamente com a voz. Tratase de uma proposta na qual ela traz ideias sobre o assobio como proposta pedagógica e criativa no ensino da música. Apresentando relevante contextualização sobre o seu uso em diversas comunidades do Rio de Janeiro, a autora ressalta a importância desta prática sonora como elemento identitário desta cidade. A identidade sonora 
é uma marca bastante presente no arcabouço teórico-metodológico do ensino de música que constitui as pedagogias musicais abertas. Depois de trazer esta visão, ela faz uma descrição sobre como o ato de assobiar toma diferentes acepções em diferentes culturas.

Algo que desperta a atenção em sua abordagem diz respeito ao fato de que ela sugere que, ao introduzir o tema do assobio na sala de aula, se peça a um estudante que faça as demonstrações. A sugestão dada por ela é uma espécie de materialização da autonomia como elemento motor da expressão criadora (DIDIER, 2018, 2020 a, 2020b). Após apresentar algumas formas de ensinar aos estudantes os diferentes modos de assobiar, ela, a partir de uma sugestão de desdobramento de atividades, dá-nos uma indicação de que está em pleno acordo com o quarto grupo de atividades proposto por Gainza (2013), que diz respeito a uma análise mais estrutural das obras. Isto porque nas duas atividades ela sugere "propor que toquem uma música do grupo" e, em seguida, "propor que criem um arranjo de assobios para a mesma música" (p. 140), mostram. Ao sugerir tal sequência, podemos perceber que a autora manifesta uma intenção de que, no decorrer da atividade, os estudantes possam desenvolver uma percepção sobre o arranjo feito analisando todas as vozes e os movimentos feitos por elas. Assim, há uma possibilidade de que, à medida que o arranjo criado pelos estudantes é executado, se possa observá-lo harmonicamente e perceber como as diferentes vozes são conduzidas.

Aproveitando esta atividade sugerida por Didier (2019), é possível observar também uma relação imediata dela com o segundo grupo de atividades que Gainza (2013) considera relevantes para que se faça uma práxis musical integrada no contexto das pedagogias abertas: o desenvolvimento de atividades criativas que contribuem para o desenvolvimento auditivo. Afirmamos isto pelo fato de que, ao executar uma única melodia, o grupo se perceberá assobiando um mesmo conjunto de sonhos e, no segundo estágio, executará melodias interdependentes, mas ainda assim precisará exercitar uma importante tarefa de escuta das outras vozes que estão sendo executadas simultaneamente.

Ainda sobre as atividades que giram em torno do desenvolvimento auditivo proposto por Gainza (2013), citamos a ideia proposta por Brito (2019), na qual a autora propõe pensar a escuta como jogo. Neste direcionamento, ela propõe pensar com os estudantes sobre as mais variadas capacidades auditivas dos seres vivos, por exemplo. Assim, pode-se, a partir da percepção sonora, fazer comparações entre as intensidades dos sons produzidos por cada um dos animais apresentados. Isto se dá pelo fato de que a escuta atende a uma dupla articulação: ela é, por um lado, uma forma de pensamento e, por outro, ato de criação (SANTOS, 2006 apud BRITO, 2019, p. 69). E é neste sentido que a autora frisa ser importante "estimular o desenvolvimento de escutas atentas [porque dizem respeito ao pensamento] e criativas [porque é assim que poderemos externar formas de criação sonora]" (p. 69).

\section{Finalizando... ou abrindo novos começos?}

Finalizando este percurso, é preciso explicitar que tivemos por intenção aqui trazer algumas concepções acerca da criação musical dentro - e a partir - do contexto das pedagogias musicais abertas. Buscamos aqui caracterizar as principais ideias que as constituem, trazendo um aporte histórico, assim como teórico-conceitual e prático. Neste sentido, cabe ainda ressaltar que as ideias que constituem as 
pedagogias musicais abertas - como a ideia de nova práxis de ensino de música, de ensino de música na contemporaneidade - estão sendo remetidas historicamente ali pelo final dos anos 80 . Considerando que se trata de uma linha de força que se põe contra uma determinada corrente ao longo do tempo, estas ideias ainda estão em movimento constante atualmente e se solidificando aos poucos.

Longe de esgotar os assuntos, procuramos na primeira parte trazer uma problematização acerca das pedagogias musicais abertas, suas origens, suas questões e inquietações. Procuramos, no decorrer da caracterização, explicitar que as pedagogias abertas requerem um esforço para uma mudança pedagógica em duas dimensões. Por um lado, uma dimensão filosófica no ensino de música, ou seja, requer uma abertura, uma mudança no pensamento sobre o que é ensinar música. Por outro lado, requer uma mudança prática, um esforço para que a forma de ensinar música integre outros saberes, outras concepções de música e um amplo protagonismo dos estudantes envolvidos, o que já vem acontecendo há algum tempo.

Buscamos também, a partir de um recorte histórico e conceitual, caracterizar a criação musical dentro das pedagogias musicais abertas. Assim, a partir das ideias de Violeta de Gainza, buscamos apresentar a criação do conceito de criatividade na pedagogia moderna. A autora aposta numa ideia de criação musical que dê conta da busca dos estudantes por explorar suas formas de expressão, suas próprias regras e modos de pensar o jogo criativo, usando materiais diversos dentro dos mais variados estilos musicais e técnicas.

Considerando que as práticas criativas nas pedagogias musicais abertas se dão, em grande parte, a partir da figura do professor, acreditamos ser de fundamental importância falar do tripé formação/atuação/avaliação. Isto porque, conforme indicou o texto, a temática da criação musical (independentemente de ser no prisma das pedagogias musicais abertas) ainda preocupa - e sempre preocupará - aqueles que formam os professores de música. No debate sobre a atuação de professores de música, foi possível perceber que a atuação pedagógica que traz práticas criativas coloca-nos um duplo desafio. Por um lado, é preciso defender as práticas criativas no processo de formação inicial de professores de música e produzir mais pesquisas tendo este tema como fio condutor das ações. Por outro, é preciso, dentro desses percursos formativos, tematizar as pedagogias musicais abertas a partir dos referenciais latino-americanos.

Já em relação à avaliação, foi possível perceber que é preciso ter atenção para que não se corra o risco de reforçar uma avaliação mensurativa, que busque "medir" o processo de criação de estudantes. Em detrimento disso, é preciso fazer um procedimento colaborativo de avaliação entre professor e estudantes, fazendo compartilhamentos, registros e análises das composições feitas no decorrer dos processos.

Apostamos também em apresentar de forma descritiva algumas propostas práticas de abordagens da criação/criatividade musical a partir das pedagogias abertas, sem ter a pretensão de fazer uma espécie de revisão bibliográfica. A intenção foi apresentar alguns autores que têm forjado atividades e metodologias criativas com base no pensamento pedagógico-musical forjado nas pedagogias abertas.

Gainza (2013) comenta que vivemos os dias dos novos paradigmas em educação musical. Isto significa dizer que as pedagogias musicais abertas requerem a possibilidade de introdução de outras temáticas e questões que, por vezes, até fogem ao que está previamente proposto no escopo do debate inicial. 
Assim sendo, pensamos ser de fundamental importância produzir pesquisas para trazermos em escritos futuros a questão da criação musical de dentro de uma perspectiva pedagógico-musical decolonial, antirracista, antiLGBTfóbica, ainda sob o prisma das pedagogias musicais abertas ou, de forma mais ousada, extrapolando-as. Tal assertiva é tomada em conta pelo fato de que é preciso conviver com determinados grupos sociais para poder compreender, praticar para caracterizar e vivenciar para difundir suas formas criativo-musicais.

Para tal, pensamos ser um desafio construir um instrumental teórico-conceitual que possa, aos poucos, dar conta das especificidades destes grupos. Temos, de forma ainda inicial, apostado no debate acerca da interseccionalidade, ou seja, de como diferentes marcadores de forma entrecruzada afetam os processos criativos em música e como podem, de alguma forma, extrapolar inclusive as ideias propostas pelas pedagogias musicais abertas. 


\section{REFERÊNCIAS}

AHARONIÁN, Coriún. Educación, Arte, Música. 2. ed. rev. Montevidéu: Tacuabé, 2013.

BALDERRABANO, Sergio. El maestro de Música como Músico. In: SIMONOVICH, Alejandro. Apertura, identidad y musicalización: bases para una educación musical latinoamericana. Buenos Aires: Foro Latinoamericano de Educación Musical - Argentina: Asociación Civil, 2009.

BATISTA, Leonardo Moraes. Educação Musical, relações étnico-raciais e decoloneidade: tensões, perspectivas e interações para a Educação Básica. Orfeu, v. 3, n. 2, p. 128-135, dez. 2018a.

BATISTA, Leonardo Moraes. Educação Antirracista e Educação Musical: interações e perspectivas para a Educação Básica. Interlúdio, ano 6, n. 10, p. 54-74, 2018b.

BEINEKE, Viviane. Aprendizagem criativa na escola: um olhar para a perspectiva das crianças sobre suas práticas musicais. Revista da Abem, Londrina, v. 19, n. 26, p. 92-104, jul./dez. 2011.

BEINEKE, Viviane. Aprendizagem criativa e educação musical: trajetórias de pesquisa e perspectivas educacionais. Educação, Santa Maria, v. 37, n. 1, p. 45-60, jan./abr. 2012.

BEINEKE, Viviane. Ensino musical criativo em atividades de composição na escola básica. Revista da Abem, Londrina, v. 23, n. 34, p. 42-57, jan./jun. 2015.

BEINEKE, Viviane. Crianças como críticos musicais em sala de aula: processos intersubjetivos na aprendizagem criativa. Opus, v. 24, n. 1, p. 153-166, jan./abr. 2018.

BRITO, Teca Alencar de. Música na educação infantil. São Paulo: Peirópolis, 2003.

BRITO, Teca Alencar de. Koellreutter educador: o humano como objetivo da educação musical. 2. ed. São Paulo: Peirópolis, 2011.

BRITO, Teca Alencar de. FLADEM - Fórum Latino-americano de Educação Musical: Por uma Educação Musical Latino-americana. Revista da Abem, Londrina, v. 20, n. 28, p. 105-117, 2012.

BRITO, Teca Alencar de. Hans-Joachim Koellreutter: ideias de mundo, de música, de educação. São Paulo: Peirópolis, 2015.

BRITO, Teca Alencar de. Um jogo chamado música: escuta, experiência, criação, educação. São Paulo: Peirópolis, 2019. 
DIDIER, Adriana Rodrigues. Língua maluca: a expressão criadora na educação musical. In: CONFERÊNCIA REGIONAL LATINO-AMERICANA DE EDUCAÇÃO MUSICAL DA ISME, 11., 2017, Natal. Anais [...]. Natal: Abem, 2017. Disponível em: http://abemeducacaomusical.com.br/conferencias/index.php/isme/2017/paper/ viewFile/2282/1154. Acesso em: 10 abr. 2021.

DIDIER, Adriana Rodrigues. Expressão criadora: revisando o conceito. In: SIMPOM, 5., 2018, Rio de Janeiro. Anais [...]. Rio de Janeiro: Unirio, 2018. Disponível em: http://www.seer.unirio.br/index.php/simpom/article/view/7706/6657. Acesso em: 11 abr. 2021.

DIDIER, Adriana Rodrigues. Assobiando uma proposta; In: BRITO, Teca Alencar de. Um jogo chamado música: escuta, experiência, criação, educação. São Paulo: Peirópolis, 2019. p. 139-141

DIDIER, Adriana Rodrigues. Autonomia por Paulo Freire: uma base para a expressão criadora. In: SIMPOM, 6, 2020, Rio de Janeiro. Anais [...]. Rio de Janeiro: Unirio, 2020a. Disponível em: http://www.seer.unirio.br/index.php/simpom/ article/view/10661/9157. Acesso em: 11 abr. 2021.

DIDIER, Adriana Rodrigues. Em busca da expressão criadora: circulação de ideias e o pensamento latino-americano na educação musical. 2020. Tese (Doutorado em Música) - Programa de Pós-Graduação em Música, Centro de Letras e Artes, Universidade Federal do Estado do Rio de Janeiro, Rio de Janeiro, 2020b.

FONTERRADA, Marisa Trench de Oliveira. Ciranda de sons [recurso eletrônico]: práticas criativas em educação musical. 1. ed. São Paulo: Editora Unesp Digital, 2015.

FRANÇA, Cecilia Cavalieri; SWANWICK, Keith. Composição, apreciação e performance na educação musical: teoria, pesquisa e prática. Em Pauta, Porto Alegre, v. 13, n. 21, p. 5-41, 2002.

GAINZA, Violeta Hemsy de. La improvisación musical. Buenos Aires: Ricordi, 1983.

GAINZA, Violeta Hemsy de. Estudos de psicopedagogia musical. Trad. Beatriz A. Canabrava. São Paulo: Summus, 1988.

GAINZA, Violeta Hemsy de. Pedagogía musical: dos décadas de pensamiento y acción educativa. Buenos Aires: Lumen, 2002.

GAINZA, Violeta Hemsy de. La educación musical en el siglo XX. Revista Musical Chilena, año LVIII, n. 201, p. 74-81, 2004.

GAINZA, Violeta Hemsy de. Temas y problemáticas de la educación musical en la actualidad. AULA: Revista de Pedagogía de la Universidad de Salamanca, v. 16, p. 33-48, 2010. 
GAINZA, Violeta Hemsy de. Educación musical siglo XXI: problemáticas contemporáneas. Revista da Abem, Londrina, v. 19, n. 25, p. 11-18, jan./jun. 2011.

GAINZA, Violeta Hemsy de. El rescate de la pedagogía musical: conferencias, escritos, entrevistas. Buenos Aires: Lumen, 2013.

LIBÂNEO, José Carlos. Didática. 2. ed. São Paulo: Cortez, 2017.

LINO, Dulcimarta Lemos; DORNELLES, Gabriel do Nascimento. Eu sabo porque sabo: a poética da improvisação na educação musical. Revista da Abem, v. 27, n. 42, p. 163-180, jan./jun. 2019.

LÓPEZ LEÓN, Ricardo. La evaluación en Educación Musical: ¿técnica, arte o problema? Guatemala: Avanti, 2015.

LUCKESI, Cipriano Carlos. Avaliação da aprendizagem escolar: estudos e proposições. 22. ed. São Paulo: Cortez, 2011.

MENDEZ, Carmen Navas. Prólogo. Hacia uma educación musical latinoamericana. San José, C. R.: Comissión Costarricense de Coopéración com la Unesco, 2004.

MENDIVIL, Luzmila. Canciones e interacciones en educación inicial. Orfeu, v. 2, n. 2, p. 91-113, dez. 2017.

MORANDIN, María Cristina; EYMANN, Sylvia \& SHAPIRO, Alicia. ¿Cómo evaluamos? la naturaleza del arte y sus implicaciones en la evaluación educativa. In:

SIMONOVICH, Alejandro. Apertura, identidad y musicalización: bases para una Educación Musical Latinoamericana. Ciudad Autónoma de Buenos Aires: Foro Latinoamericano de Educación Musical - Argentina Asociación Civil, 2009. p. 89-95.

SANTOS, Regina Marcia Simão. Já não chega do modelo da recognição? incursões sobre Educação Musical, Pedagogias Abertas e o pensamento de H. J. Koellreutter. In: SEMINÁRIO DE PESQUISA EM MÚSICA DA UFG, 17.; SEMINÁRIO NACIONAL DO FÓRUM LATINOAMERICANO DE EDUCAÇÃO MUSICAL, 1., 2017, Goiânia. Anais [...]. Goiânia: SEMPEM; FLADEM-Brasil, 2017. p. 480-489.

SARDO, Fernando. Criar instrumentos e músicas. In: BRITO, Teca Alencar de. Um jogo chamado música: escuta, experiência, criação, educação. São Paulo: Peirópolis, 2019. p. 155-156.

STOKOE, Patricia. Reflexiones sobre la educación y los procesos creativos. In: GAINZA, Violeta Hemsy de (ed.). Música y educación hoy. Buenos Aires: Lumen, 1997. p. 57-59. 
SWANWICK, Keith. Ensinando música musicalmente. Trad. Alda Oliveira e Cristina Tourinho. São Paulo: Moderna, 2003.

VINCENZI, Alejandro de. Sistema vs. Sistema. Colonialismo académico e identidad cultural. In: SIMONOVICH, Alejandro. Apertura, identidad y musicalización: bases para una Educación Musical Latinoamericana. Ciudad Autónoma de Buenos Aires: Foro Latinoamericano de Educación Musical Argentina Asociación Civil, 2009. p. 59-67. 